\title{
8. MIOCENE TO PLEISTOCENE SILICOFLAGELLATES FROM THE CENTRAL NORTH PACIFIC, DEEP SEA DRILLING PROJECT LEG 62 1
}

\author{
Carla Müller, Geologisch-Paläontologisches Institut der Universität Frankfurt am Main, Federal Republic \\ of Germany
}

\section{INTRODUCTION}

Interest in silicoflagellates as a biostratigraphic tool and as environmental indicators has increased in recent years. Many new results, mainly obtained by investigations of DSDP cores, have resulted in a more-detailed knowledge of their biostratigraphic and regional distribution in the oceans.

However, the taxonomy of silicoflagellates is still unsettled, as indicated by the use of different names for the same taxa. One of the reasons is probably the large number of varieties of a species resulting from particular ecological conditions.

Silicoflagellates are present only in a few levels at DSDP Site 464 (upper Miocene to lower Pliocene) and at Site 466 (Pliocene and Pleistocene), of Leg 62, in the central North Pacific (Fig. 1). Because of these restricted occurrences, it is not possible to obtain a detailed biostratigraphy.

The results are compared, as far as possible, with those given by Bukry and Foster (1973) from the eastern Pacific, by Dumitrică (1973b) from the southwestern Pacific, and by Martini $(1971,1976)$ for the equatorial and central Pacific. For correlation and discussion of the silicoflagellate zonations established by various authors for the Pacific, see Martini (1976).

Six $35-\mathrm{mm}$ rows were counted at a magnification of $\times 500$ on each slide to determine the relative abundances of species (Tables 1 and 2) in routine smear-slide preparation. The reader is referred to other publications, which provide illustrations of species mentioned in this report.

\section{BIOSTRATIGRAPHIC REMARKS}

Site 464

$\left(39^{\circ} 51,64^{\prime} \mathrm{N}, 173^{\circ} 53.33^{\prime} \mathrm{E}\right.$, depth $\left.4637 \mathrm{~m}\right)$

Site 464 is on northern Hess Rise, in the central North Pacific. Silicoflagellates are present only in Lithologic Sub-units IA and IB, of clayey siliceous ooze (Cores 2 to 3 ), and siliceous clay (Core 3 to the upper part of Core 5). The brown clay of Unit II (lower part of Core 5 to Core 10 ) is barren of calcareous nannofossils, as well as of siliceous microfossils. These sediments were deposited below the CCD.

\footnotetext{
${ }^{1}$ Initial Reports of the Deep Sea Drilling Project, Volume 62.
}

Lower water temperatures during the early Pliocene are indicated by the relative abundance of cold- to temperate-water species, such as Distephanus speculum, Mescocena elliptica, and Distephanus boliviensis, as well as by the scarcity of discoasters. Silicoflagellates are less abundant in Core 2, probably because of dilution by greater amounts of calcareous nannoplankton. Dissolution of the nannoplankton increases distinctly from Core 3 to Core 5. Also, the preservation of the siliceous microfossils becomes poor in Core 5, Section 2, where they are much broken. Core 4 , Section 3 , to Core 5 belong to the upper Miocene Distephanus crux Zone (Bukry and Foster, 1973), indicated by Distephanus crux (Ehrenberg) Haeckel, 1887 (see Martini, 1971, pl. 1 , fig. 11), a species which has its last consistent occurrence at the top of this zone. Bukry and Foster (1973) correlated this zone with the upper Miocene and lower Pliocene. However, investigations at Site 464 indicate that the top of this zone corresponds approximately with the Miocene/Pliocene boundary. The extinction of Distephanus crux at the top of the Miocene in the southwest Pacific is also mentioned by Dumitrică (1973b).

The late Miocene age of this section is confirmed by investigations of diatoms (Sancetta, this volume). Only very few specimens of Distephanus crux were reported from early Pliocene sediments. One specimen was found in Sample 464-4-1, 65-66 cm, but it is a somewhat atypical form, showing a very small apical opening (see Dumitrică, 1973b, pl. 6, fig. 11). Also, several specimens of Naviculopsis sp. were observed in Sample 464-4-3, $65-66 \mathrm{~cm}$. Species of this genus are unknown from the Pliocene. Few specimens of this genus were also mentioned by Bukry and Foster (1973) and Dumitrică (1973a) from the upper Miocene.

Distephanus boliviensis (Frenguelli) Bukry and Foster, 1973 (cannopilean) (see Martini and Müller, 1976, pl. 3, figs. 5,6) is rare in the lower Pliocene (nannoplankton Zones NN13 to NN15) at Site 464. The first specimens were found in Sample 464-4-1, 65-66 cm. It seems that this species is more common and has longer spines in areas of lower water temperatures. It is mentioned by Ciesielski (1975) in the lower Pliocene of the Antarctic (DSDP Leg 28). This species is also known from the lower Pliocene of the Norwegian-Greenland Sea (Martini and Müller, 1976). It seems to be a useful index fossil for this interval.

Mesocena elliptica (Ehrenberg) Ehrenberg, 1844 (see Bukry and Foster, 1973, pl. 6, figs. 2-4) is common in 


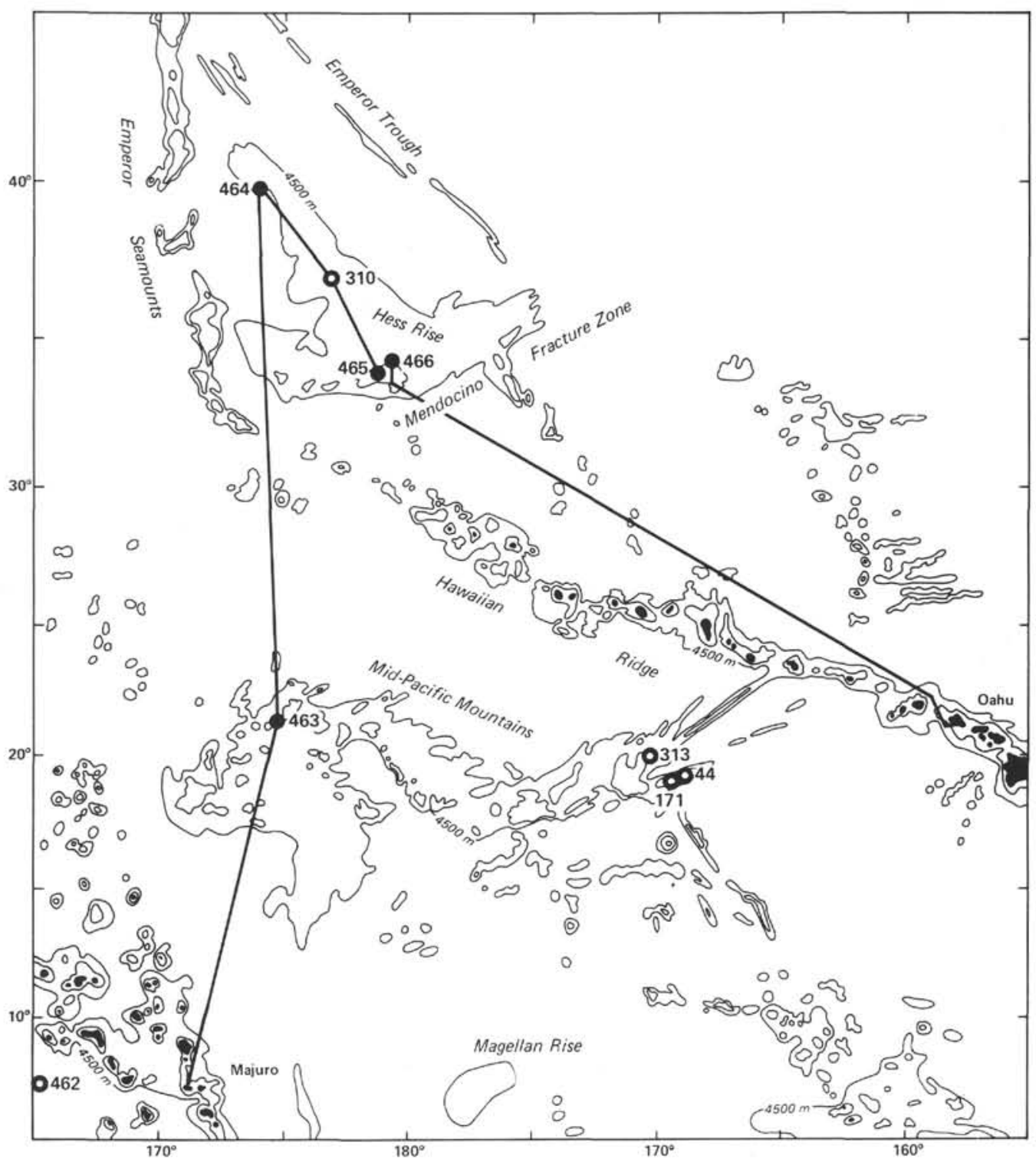

Figure 1. Location of Sites drilled in the north-central Pacific during DSDP Leg 62.

the lower Pliocene of Core 3. It is also mentioned by Ciesielski (1975) from this stratigraphic interval.

Bukry and Foster (1973) correlate their Mesocena elliptica Zone with the uppermost Pliocene and lower to middle Pleistocene. It is characterized by this species in abundance. Also, Dumitrică $(1973 a, b)$ indicated the abundance of Mesocena elliptica in the Quaternary of the southwest Pacific and the Mediterranean, and Martini (1971) established an upper Pliocene to Holocene Mesocena quadrangula Zone in the Equatorial Pacific. (Mesocena quadrangula is a junior synonym of Mesocena elliptica.) However, in the Leg 62 material this species is present only in the lower Pliocene. It was not observed in the Pleistocene at Site 466.

Mesocena circulus (Ehrenberg) Ehrenberg, 1844 (see Bukry and Foster, 1973, pl. 5, fig. 9) is described by Ciesielski (1975) only from the upper Miocene. The extinction of this species is used by Martini and Müller
(1976) to define the top of the Mesocena circulus Zone (middle-upper Miocene) in the Norwegian-Greenland Sea. These observations do not correspond to results at Site 464; Mesocena circulus is still present in the lower Pliocene and sporadically in the Pleistocene (Site 466). This is also known from other areas (Tasmanian Sea, South Atlantic, Southwest Pacific).

Mesocena diodon Ehrenberg, 1844 (see Bukry and Foster, 1973, pl. 6, figs. 6,7) is rare and only present in the lower Pliocene, as also mentioned by other authors. Bukry and Foster (1973) and Dumitrică (1973b) found this species only in the Miocene of the east Pacific and the southwest Pacific. Further common species in the upper Miocene-lower Pliocene at Site 464 are Dictyocha fibula Ehrenberg, 1839 (see Bukry and Foster, 1973, pl. 3, fig. 1), Dictyocha aspera Lemmermann, 1901 (see Bukry and Foster, 1973, pl. 2, fig. 4; Dumitrică, 1973a, pl. 4, figs. 5-7,9), and Distephanus speculum Ehren- 
Table 1. Distribution of silicoflagellates in selected samples from DSDP Site 464.

\begin{tabular}{|c|c|c|c|c|c|c|c|c|c|c|c|c|}
\hline $\begin{array}{c}\text { Sample } \\
\text { (interval in cm) }\end{array}$ & 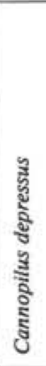 & 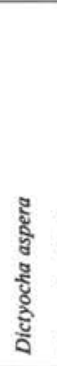 & 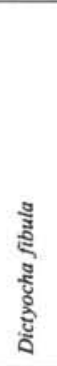 & 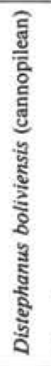 & 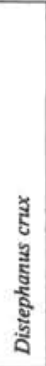 & 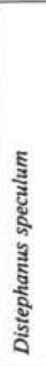 & $\begin{array}{l}\text { है } \\
\text { हूँ } \\
\text { हूँ } \\
\text { हूँ }\end{array}$ & 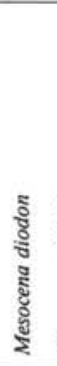 & 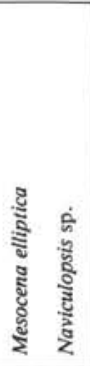 & $\begin{array}{c}\text { Nannoplankton Zones } \\
\text { (Martini, 1971) }\end{array}$ & $\begin{array}{l}\text { Silicoflagellate Zones } \\
\text { (Bukry and Foster, } \\
\text { 1973; this report) }\end{array}$ & Age \\
\hline $\begin{array}{c}464-2-1,120-122 \\
2-3,120-121 \\
3-1,71-72 \\
3-3,71-72 \\
4-1,65-66 \\
\end{array}$ & 4 & $\begin{array}{r}2 \\
20 \\
33 \\
26 \\
89 \\
\end{array}$ & $\begin{array}{r}16 \\
14 \\
52 \\
116 \\
15 \\
\end{array}$ & $\begin{array}{l}2 \\
2 \\
2 \\
5 \\
\end{array}$ & cf. & $\begin{array}{r}3 \\
6 \\
37 \\
22 \\
45 \\
\end{array}$ & $\begin{array}{r}8 \\
4 \\
15 \\
32 \\
15 \\
\end{array}$ & $\begin{array}{l}2 \\
1 \\
1 \\
1 \\
7 \\
\end{array}$ & $\begin{array}{l}39 \\
17\end{array}$ & $\begin{array}{c}\text { NN15 } \\
\text { to } \\
\text { NN13 } \\
-\end{array}$ & $\begin{array}{l}\text { Distephanus } \\
\text { boliviensis }\end{array}$ & $\begin{array}{l}\text { Early } \\
\text { Ptiocene }\end{array}$ \\
\hline $\begin{array}{l}4-3,65-66 \\
5-1,56-57 \\
5-2,56-57\end{array}$ & & $\begin{array}{l}27 \\
30 \\
40\end{array}$ & $\begin{array}{r}7 \\
8 \\
12\end{array}$ & & $\begin{array}{l}1 \\
4 \\
3\end{array}$ & $\begin{array}{l}8 \\
6 \\
3\end{array}$ & 6 & & 10 & $\begin{array}{c}\text { Barren of } \\
\text { nannoplankton }\end{array}$ & $\begin{array}{l}\text { Distephamus } \\
\text { crux }\end{array}$ & $\begin{array}{l}\text { Late } \\
\text { Miocene }\end{array}$ \\
\hline
\end{tabular}

Table 2. Distribution of silicoflagellates in selected samples from DSDP Site 466.

\begin{tabular}{|c|c|c|c|c|c|}
\hline $\begin{array}{c}\text { Sample } \\
\text { (interval in } \mathrm{cm} \text { ) }\end{array}$ & 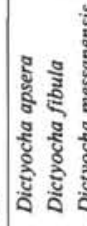 & 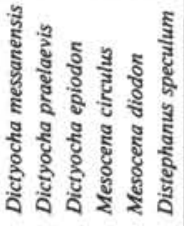 & $\begin{array}{c}\text { Nannoplankton Zones } \\
\text { (Martini, 1971) }\end{array}$ & $\begin{array}{l}\text { Silicoflagellate Zones } \\
\text { (Bukry and Foster, } \\
\text { 1973; this report) }\end{array}$ & Age \\
\hline $\begin{array}{c}466-1-1,30-31 \\
1-1,100-101 \\
1-5,69-70 \\
\end{array}$ & 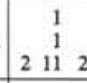 & 61 & $\mathrm{NN} 20-21$ & \multirow[b]{2}{*}{ Dictyocha epiodon } & \multirow[b]{2}{*}{ Quaternary } \\
\hline $\begin{array}{l}2-2,120-122 \\
2-6,120-122 \\
3-2,60-61 \\
3-3,60-61 \\
4-1,65-66\end{array}$ & $\begin{array}{rrr} & & \\
5 & 8 \\
9 & 25 & 3 \\
14 & 18 & 2 \\
\end{array}$ & $\begin{array}{ccc} & \text { (barren) } \\
& 2 & 2 \\
3 & 9 & 10 \\
2 & 6 & 6 \\
\end{array}$ & NN19 & & \\
\hline $\begin{array}{l}5-2,80-81 \\
5-4,80-81\end{array}$ & 2 & 1 & NN15-16 & \multirow[t]{2}{*}{ - } & \multirow[b]{2}{*}{$\begin{array}{c}\text { Early } \\
\text { Pliocene }\end{array}$} \\
\hline $\begin{array}{l}6-2,90-91 \\
6-5,79-80 \\
7-2,70-72\end{array}$ & 1 & (barren) & NN14 & & \\
\hline
\end{tabular}

berg) Haeckel, 1887 (see Bukry and Foster, 1973, pl. 5, fig. 8). (Dictyocha ausonia Deflandre, 1950, and Dictyocha rhombica (Schulz) Deflandre, 1941 are junior synonyms of Dictyocha aspera.)

\section{Site 466 \\ $\left(34^{\circ} 11.46^{\prime} \mathrm{N}, 179^{\circ} 15.34^{\prime} \mathrm{E}\right.$, depth $2665 \mathrm{~m}$ )}

Site 466 is on southern Hess Rise. Silicoflagellates are present in the Pleistocene and very rare in the Pliocene. The assemblages are of low diversity. Dictyocha epiodon Ehrenberg, 1844 (Dictyocha fibula var. aculeata Lemmermann, 1901 is considered a junior synonym; see Martini, 1971, pl. 1, fig. 5; Bukry and Foster, 1973, pl. 2, figs. 7,8 ) occurs in the Pleistocene (nannoplankton Zones NN19 to NN21), together with Dictyocha fibula Ehrenberg, 1839, Dictyocha praelaevis Frenguelli, 1951 (see Dumitrică, 1973b, pl. 3, figs. 8-12). Dictyocha messanensis Haeckel, 1862 (see Dumitrică, 1973a, pl. 8, figs. 8-13; 1973b, pl. 4, figs. 5-8), and Dictyocha aspera Lemmermann, 1901. According to Poelchau (1976), Dictyocha epiodon is common in the area of the Alaskan gyre and the western North Pacific. It is also known from the equatorial and southern Atlantic and the Mediterranean. Dictyocha epiodon seems to be a good index fossil for the Quaternary in certain regions.

The Pliocene sediments are extremely poor in siliceous microfossils, which might be due to dilution and (or) dissolution in the nannofossil ooze. No silicoflagellates have been found in the Eocene deposits (Cores 8 and 9).

\section{Silicoflagellate Zones}

The tropical silicoflagellate zonation given by Bukry and Foster (1973) for the east Pacific can be used partially at Sites 464 and 466 in the north-central Pacific. However, according to the results of the present study, it is necessary to combine several zones and to change the biostratigraphic intervals which were represented originally by these zones. For correlation with the nannoplankton zones, see Figure 2.

\section{Distephanus crux Zone (Bukry and Foster, 1973)}

According to the authors, the top of this zone is characterized by the last consistent occurrence of Distephanus crux, representing the upper Miocene and lower Pliocene. According to the results at Site 464, the 


\begin{tabular}{|c|c|c|c|c|}
\hline \multirow[b]{2}{*}{ Age } & \multirow{2}{*}{\multicolumn{2}{|c|}{$\begin{array}{l}\text { Nannoplankton Zones } \\
\text { (Martini, 1971) }\end{array}$}} & \multicolumn{2}{|c|}{ Silicoflagellate Zones } \\
\hline & & & $\begin{array}{l}\text { Eastern Pacific, Leg 16 } \\
\text { (Bukry and Foster, 1973) }\end{array}$ & $\begin{array}{l}\text { North-Central Pacific, Leg } 62 \\
\text { (this paper) }\end{array}$ \\
\hline \multirow{2}{*}{ Quaternary } & NN21 & E. huxleyi & Dictyocha epiodon & \multirow{2}{*}{ Dictyocha epiodon } \\
\hline & $\begin{array}{l}\text { NN20 } \\
\text { NN19 }\end{array}$ & $\begin{array}{l}\text { G. oceanica } \\
P . \text { lacunosa }\end{array}$ & Mesocena elliptica & \\
\hline $\begin{array}{c}\text { Late } \\
\text { Pliocene }\end{array}$ & $\begin{array}{l}\text { NN18 } \\
\text { NN17 } \\
\text { NN16 }\end{array}$ & $\begin{array}{l}\text { D. brouweri } \\
\text { D. pentaradiatus } \\
\text { D. surculus }\end{array}$ & \multirow{2}{*}{ Distephanus boliviensis } & $?$ \\
\hline \multirow{3}{*}{$\begin{array}{l}\text { Early } \\
\text { Pliocene }\end{array}$} & NN15 & R. pseudoumbilica & & \multirow{3}{*}{ Distephanus boliviensis } \\
\hline & NN14 & D. asymmetricus & \multirow{3}{*}{ Distephanus crux } & \\
\hline & $\begin{array}{l}\text { NN13 } \\
\text { NN12 }\end{array}$ & $\begin{array}{l}\text { C. rugosus } \\
\text { C. tricorniculatus }\end{array}$ & & \\
\hline $\begin{array}{c}\text { Late } \\
\text { Miocene }\end{array}$ & NN11 & D. quinqueramus & & Distephanus crux \\
\hline
\end{tabular}

Figure 2. Correlation between nannoplankton zones and silicoflagellate zones, based on results from Leg 62 material, compared to the correlation of Bukry and Foster (1973) for the eastern Pacific.

top of this zone seems to correspond approximately to the Miocene/Pliocene boundary.

\section{Distephanus boliviensis Zone (Bukry and Foster, 1973; emended this paper)}

The consistent occurrence of Distephanus boliviensis and Distephanus boliviensis (cannopilean) is typical of this zone. The base is defined by the first occurrence of Distephanus boliviensis (cannopilean), and the top by the extinction of Distephanus boliviensis. This zone combines the Cannopilus major Zone and the Distephanus boliviensis Zone described by Bukry and Foster (1973) for the upper lower Pliocene and upper Pliocene. According to the results of this study, the Distephanus boliviensis Zone represents the lower Pliocene (at Site 464, nannoplankton Zones NN13 to NN15). Distephanus boliviensis (cannopilean) is also mentioned from the lower Pliocene of the Norwegian-Greenland Sea (Martini and Muller, 1976), and from the Antarctic in the Distephanus boliviensis Zone established by Ciesielski (1975). According to Ciesielski, this zone includes the interval from about 4 to $3 \mathrm{~m}$.y. ago, which means that it can be correlated approximately with the nannoplankton Zones NN13 to NN15, in a good agreement with the results at Site 464 (Fig. 2).

\section{Dictyocha epiodon Zone (Bukry and Foster, 1973; emended this paper)}

This zone is characterized by the presence of Dictyocha epiodon. It is correlated with the Quaternary, corresponding to nannoplankton Zones NN19 to NN21, and it combines the Mesocena elliptica Zone and the Dictyocha epiodon Zone (Bukry and Foster, 1973). According to these authors, the Dictyocha epiodon Zone represents only the uppermost Quaternary.

\section{ACKNOWLEDGMENTS}

I want to thank the shipboard party of Leg 62 for providing samples for this study, as well as Dr. E. Martini, Frankfurt am Main, and Dr. D. Bukry, La Jolla, for critical review of the manuscript.

\section{REFERENCES}

Bukry, D., and Foster, J. H., 1973. Silicoflagellate and diatom stratigraphy, Leg 16, Deep Sea Drilling Project. In van Andel, Tj. H., Heath, G. R., et al., Init. Repts. DSDP, 16: Washington (U.S. Govt. Printing Office), 815-871.

Ciesielski, P. F., 1975. Biostratigraphy and paleoecology of Neogene and Oligocene silicoflagellates from cores recovered during Antarctic Leg 28, Deep Sea Drilling Project. In Hayes, D. E., Frakes, L. A., et al., Init. Repts. DSDP, 28: Washington (U.S. Govt. Printing Office), 625-691.

Dumitrică, P., 1973a. Miocene and Quaternary silicoflagellates in sediments from the Mediterranean Sea. In Ryan, W. B. F., Hsü, K. J., et al., Init. Repts. DSDP, 13: Washington (U.S. Govt. Printing Office), 902-933.

1973b. Paleocene, late Oligocene and post-Oligocene silicoflagellates in southwestern Pacific sediments cored on DSDP Leg 21. In Burns, R. E., Andrews, J. E., et al., Init. Repts. DSDP, 21: Washington (U.S. Govt. Printing Office), 837-883.

Loeblich, A. R., III, Loeblich, L. A., Tappan, H., et al., 1968. Annoted index of fossil and recent silicoflagellates and ebridians with descriptions and illustrations of validly proposed taxa. Geol. Soc. Am. Mem., 106.

Martini, E., 1971. Neogene silicoflagellates from the equatorial Pacific. In Winterer, E. L., Riedel, W. R., et al., Init. Repts. DSDP, 7, Pt. 2: Washington (U.S. Govt. Printing Office), 1695-1708.

1976. Neogene and Quaternary silicoflagellates from the central Pacific Ocean (DSDP Leg 33). In Schlanger, S. O., Jackson, E. D., et al., Init. Repts. DSDP, 33: Washington (U.S. Govt. Printing Office), 439-449.

Martini, E., and Müller, C., 1976. Eocene to Pleistocene silicoflagellates from the Norwegian-Greenland Sea (DSDP Leg 38). In Talwani, M., Udintsev, G., et al., Init. Repts. DSDP, 38: Washington (U.S. Govt. Printing Office), 857-895.

Poelchau, H. S., 1976. Distribution of Holocene silicoflagellates in North Pacific sediments. Micropaleont., 22(2):164-193. 